\title{
Comparative Study on Carbonated and Non-Carbonated Recycled Aggregate Concrete with Glass Powder as Partial Replacement for OPC
}

\author{
https://doi.org/10.3991/ijes.v5i4.7766 \\ Abhishek Patil $\left.{ }^{\bowtie}\right)$, Rahul Hatti, Darshan Patil, Rakesh Kumar \\ Basaveshwar Engineering College, Bagalkot, Karnataka, India \\ abhishekpatil2991994@gmail.com
}

\begin{abstract}
Recycled aggregates (RA) possess the ability to be recycled, if undesirable properties are counteracted viz, porous mortar attached to it, with high water absorption and low density, this technique, accelerated carbonation can be one such to technique to counteract undesirable properties of RA, replacement of $20 \%$ of cement by glass powder assists in reducing $\mathrm{w} / \mathrm{c}$ ratio ${ }^{[1][6]}$ when used in concrete ${ }^{[2]}$ suppress ASR reaction ${ }^{[1]}$, this paper explains a new possibility of recycling concrete, work done and findings for improvising Recycled aggregate concrete (RAC) and exploring the feasibility for use of RA in the near future.
\end{abstract}

Keywords-Recycled aggregate, carbonation of recycled aggregate, recycled aggregate concrete.

\section{Introduction}

Due to rapid growth in the population and industry the demand for natural sources has increased which are reducing availability of resources and creating stress on natural resources, hence in order to fulfill the demand there is necessity to find alternate source and recycle materials back to industry, and closed loop recycling is the most appropriate sustainable methodology to reuse waste streams back into new production as it will create energy saving, reduce the demand on primary resources and deviate waste from reaching landfills nevertheless in some circumstances, waste streams cannot be reused in the production of new material of their restriction applied on quality, Several studies have been carried out to study feasibility of industrial waste and rejects, as pozzolanic and aggregates wastes like slag, rice husk ash, plastic, glass etc. in concrete, milled glass powder is a potential substitute for cement, Use of glass in construction application as a replacement for cement provided to be advantageous. Glass powder fine and possess pozzolanic property, when it is partially replaced assists in formation of $\mathrm{CSH}$ gel suppress ASR reaction and reduces w/c when in concrete $^{[1]}$.

Due to the limited life of concrete structures large amount of structures are being demolished for erection of new and the debris of which causes again the problem of 
landfill and environmental impacts. Hence aggregates obtained from C\&D waste can be utilized as partial substitute for natural aggregate in new concrete, but due to their previous usage these aggregates surrounded by inter-transition zone mortar, develop undesirable properties such as high water absorption, prone to cracks under loading and weaker transition zone, limits the usage of these aggregates at higher content hence incorporation of glass powder will counteract the problem of water absorp$\operatorname{tion}^{[5][6]}$ and further carbonation of recycled aggregate in which $\mathrm{CO} 2$ reacts with hydrated and un-hydrated byproducts of mortar attached to RA to form $\mathrm{CaCo}^{[7]}$, which is formulated by the following reactions ${ }^{[7]}$.

$\mathrm{Ca}(\mathrm{OH})_{2}+\mathrm{CO}_{2} \rightarrow \mathrm{CaCO}_{3}+\mathrm{H}_{2} \mathrm{O}$

$\mathrm{C}-\mathrm{S}-\mathrm{H}+\mathrm{CO}_{2} \rightarrow \mathrm{CaCO}_{3}+\mathrm{SiO}_{2} \cdot \mathrm{nH}_{2} \mathrm{O}$

$3 \mathrm{CaO} \cdot \mathrm{Al}_{2} \mathrm{O}_{3} \cdot \mathrm{CaSO}_{4} \cdot 32 \mathrm{H}_{2} \mathrm{O} \rightarrow \mathrm{Al}_{2} \mathrm{O}_{3} \cdot \mathrm{nH}_{2} \mathrm{O}+3 \mathrm{CaCO}_{3}+3\left(\mathrm{CaSO}_{4} \cdot 2 \mathrm{H}_{2} \mathrm{O}\right)+(26-\mathrm{n}) \mathrm{H}_{2} \mathrm{O}$

$2 \mathrm{CaO} . \mathrm{SiO}_{2}+2 \mathrm{CO}_{2}+\mathrm{nH}_{2} \mathrm{O} \rightarrow 2 \mathrm{CaCO}_{3}+\mathrm{SiO}_{2}+\mathrm{nH}_{2} \mathrm{O}$

$3 \mathrm{CaO} . \mathrm{SiO}_{2}+3 \mathrm{CO}_{2}+\mathrm{nH}_{2} \mathrm{O} \rightarrow 3 \mathrm{CaCO}_{3}+\mathrm{SiO}_{2}+\mathrm{nH}_{2} \mathrm{O}$

The hydrated bi-products present in attached cement mortar C-S-H , $\mathrm{Ca}(\mathrm{OH})_{2}$, ettringite (calcium trisulpho aluminate) and calcium mono-aluminate and un-hydrated cement particles containing $\mathrm{C} 3 \mathrm{~S}$ and $\mathrm{C} 2 \mathrm{~S}$ are carbonated to form calcium carbonate, this calcium carbonate formed, fills the micro pores present in attached cement mortar which decreases porosity and water absorption and increases the density of recycled aggregate ${ }^{[7]}$.

\section{Material Preparation}

- Milled Glass Powder: particle size $>80 \mu$ and above with specific gravity 2.6 with chemical composition as shown in Table 1.

- Recycled Aggregate and Processing: Recycled aggregate (Fig.1) from demolition waste was crushed and processed trough Los Angles abrasion machine for 500 revolutions (Fig.3) and showered in water spray to minimize and wash the mortar surrounding RA (Fig.2)

- Accelerated carbonation chamber: accelerated carbonation chamber is an air tight sealed container where compressed $\mathrm{CO}_{2}$ is maintained at pressure around 0.2 to $0.4 \mathrm{MPa}$, with $50-60 \%$ relative humidity $(\mathrm{RH})$ with concentrated brine solution (water $+\mathrm{NaCl}$ ) to prevent formation of carbonic acid on reacting with water (Fig.4 $+5)$ aggregates are processed for period of 48 hours.

Table 1. chemical composition of glass powder

\begin{tabular}{|l|c|c|c|c|c|c|}
\hline Composition & Silica(SiO) & $\begin{array}{c}\text { Calcium } \\
\mathbf{o x}- \\
\text { ide(CaO) }\end{array}$ & $\begin{array}{c}\text { Magnesi- } \\
\text { um Oxide } \\
(\mathbf{M g O})\end{array}$ & $\begin{array}{c}\text { Sodium } \\
\mathbf{O x}- \\
\text { ide(Na } \mathbf{O} \mathbf{O})\end{array}$ & $\begin{array}{c}\text { Alumina } \\
\left(\mathbf{A l}_{\mathbf{2}} \mathbf{O}_{\mathbf{3}}\right.\end{array}$ & $\begin{array}{c}\text { Iron Oxide } \\
\mathbf{( F e}_{\mathbf{2}} \mathbf{O}_{\mathbf{3}}\end{array}$ \\
\hline Content (\%age) & 72 & 20 & 2.5 & 10.2 & 0.5 & 3.5 \\
\hline
\end{tabular}


Short Paper-Comparative Study on Carbonated and Non-Carbonated Recycled Aggregate Concrete with...

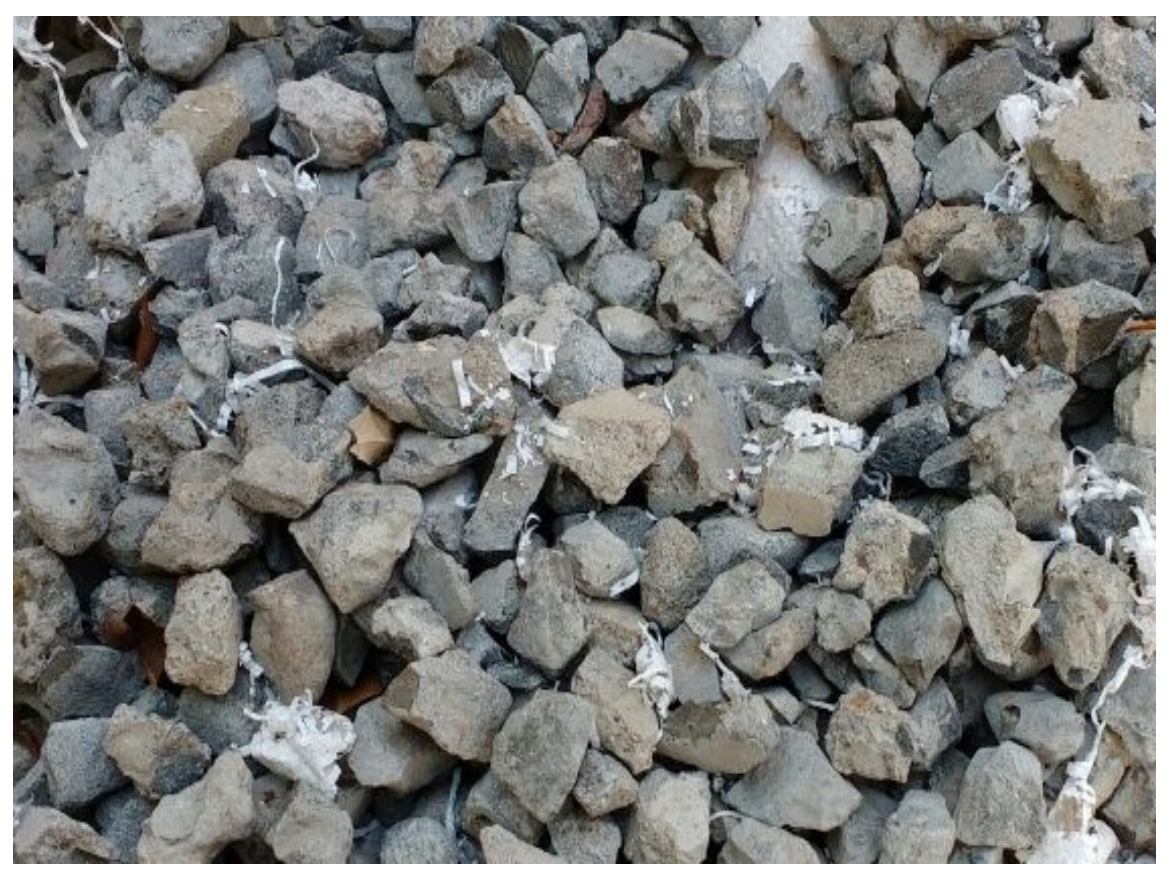

Fig. 1. RA before abrasion

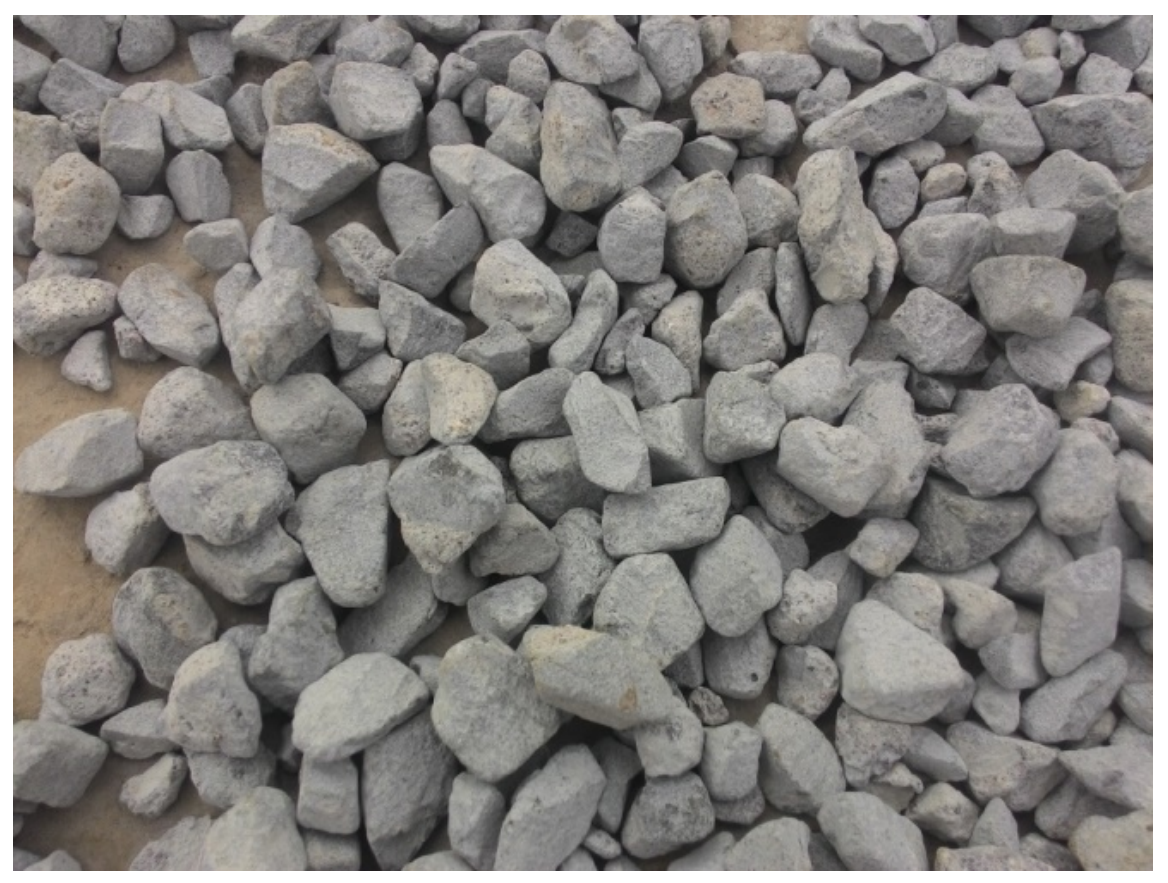

Fig. 2. RA after abrasion 
Short Paper-Comparative Study on Carbonated and Non-Carbonated Recycled Aggregate Concrete with...

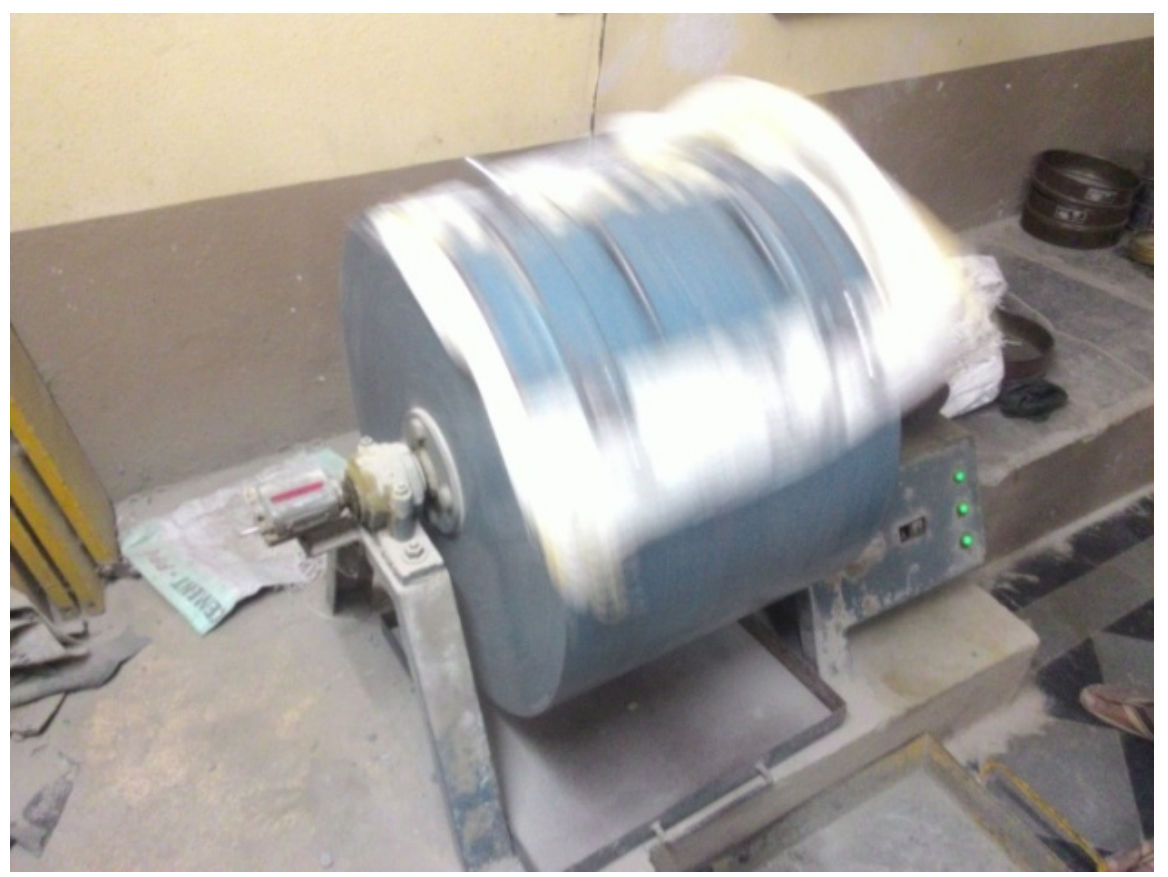

Fig. 3. Los Angles abrasion machine

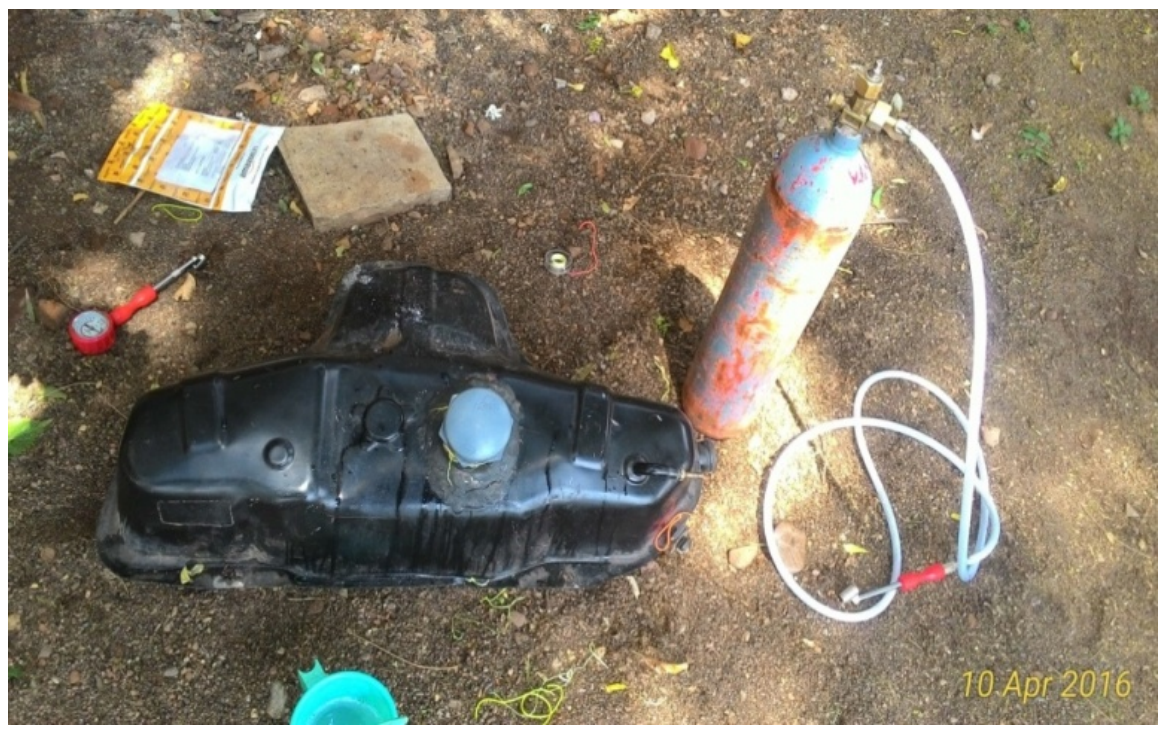

Fig. 4. Carbonation Chamber set-up 


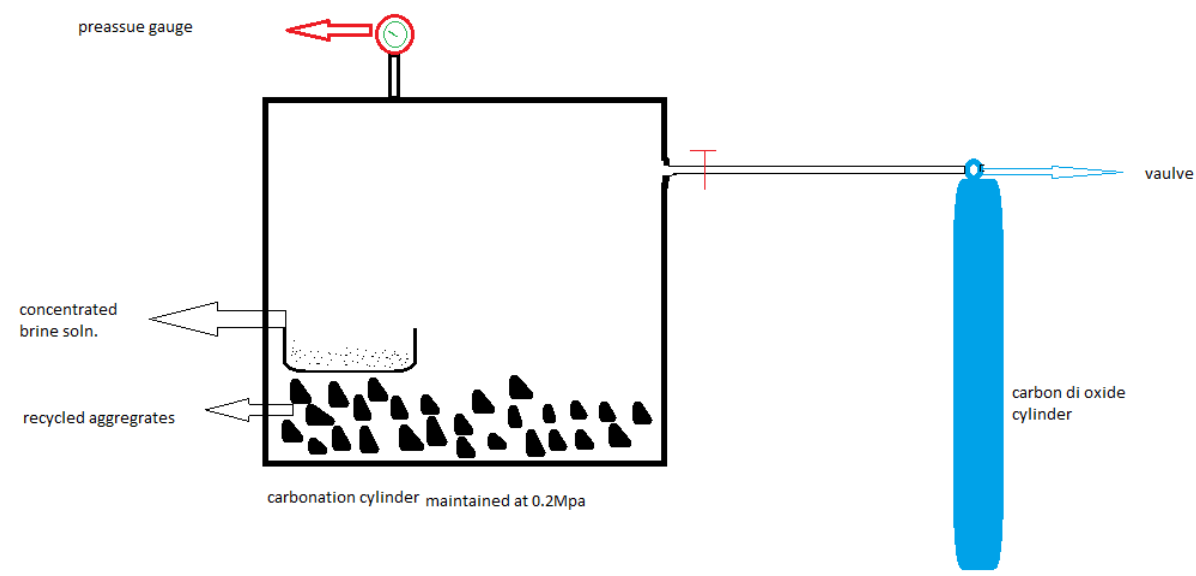

Fig. 5. Carbonation chamber line diagram

\section{Tests on Recycled Aggregates and Concrete}

\subsection{Test on recycled aggregates}

Table 2. Physical properties of carbonated and non-carbonated RA

\begin{tabular}{|l|c|c|}
\hline & Water absorption (\%) & Specific gravity \\
\hline Non-carbonated & 2.38 & 3 \\
\hline Carbonated & 2.17 & 3.17 \\
\hline
\end{tabular}

\subsection{Workability of concrete}

Slump cone test is carried out to determine the workability of the concrete. Slump values of different mixes are given in Table 3.

Table 3. Slump values for different mixes

\begin{tabular}{|c|c|c|c|c|c|}
\hline & \multicolumn{5}{|c|}{ SLUMP VALUE (mm) } \\
\hline & $\begin{array}{c}\text { Conven- } \\
\text { tional }\end{array}$ & $\begin{array}{c}40 \% \text { re- } \\
\text { placement }\end{array}$ & $\begin{array}{c}60 \% \text { replace- } \\
\text { ment }\end{array}$ & $\begin{array}{c}80 \% \text { replace- } \\
\text { ment }\end{array}$ & $\begin{array}{c}100 \% \text { replace- } \\
\text { ment }\end{array}$ \\
\hline Non-carbonated RAC & 140 & 110 & 122 & 143 & 152 \\
\hline Carbonated RAC & 140 & 115 & 130 & 151 & 161 \\
\hline
\end{tabular}

\subsection{Compressive strength test}

Compressive strength test was carried out on the cubes having size of $150 \mathrm{~mm} \times 150 \mathrm{~mm} \times 150 \mathrm{~mm}$ as per IS516(1959) and the corresponding results have been tabulated in Table 4. 
Table 4. Compressive strength of non-carbonated and carbonated RAC

\begin{tabular}{|l|c|c|c|c|c|}
\hline & \multicolumn{5}{|c|}{ COMPRESSIVE STRENGTH $\left(\mathrm{N} / \mathbf{m m}^{2}\right)$} \\
\hline & $\begin{array}{c}\text { 0\% conven- } \\
\text { tional }\end{array}$ & $\begin{array}{c}\text { 40\% replace- } \\
\text { ment }\end{array}$ & $\begin{array}{c}\text { 60\% replace- } \\
\text { ment }\end{array}$ & $\begin{array}{c}\text { 80\% replace- } \\
\text { ment }\end{array}$ & $\begin{array}{c}\text { 100\% re- } \\
\text { placement }\end{array}$ \\
\hline Non-carbonated RAC & 26.12 & 28.48 & 26.59 & 25.14 & 22.79 \\
\hline Carbonated RAC & 26.12 & 28.08 & 26.19 & 25.00 & 22.50 \\
\hline
\end{tabular}

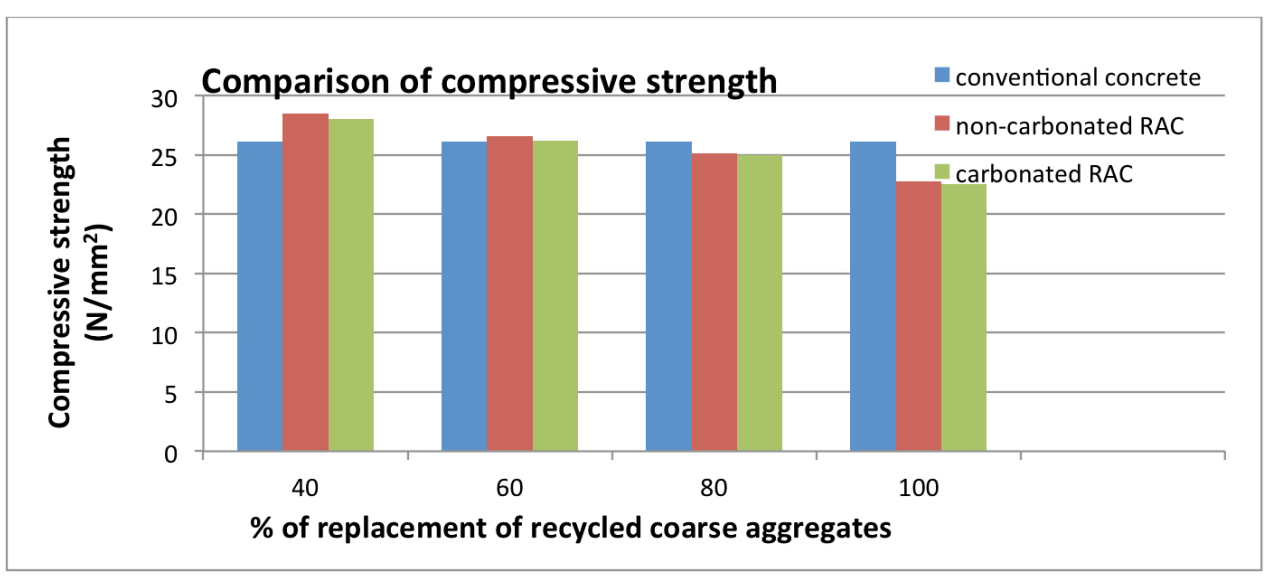

Fig. 6. Comparison of compressive strength of non-carbonated and non-carbonated RAC with conventional concrete

\subsection{Tensile strength test}

Split tensile strength was carried out on cylinders having length of $200 \mathrm{~mm}$ and diameter of $100 \mathrm{~mm}$ as per IS 5816 (1999).

The tensile strength of concrete cylinders containing non-carbonated and carbonated recycled aggregates on 28th day are represented in Table 5.

Table 5. Tensile strength of non-carbonated and carbonated recycled aggregate concrete

\begin{tabular}{|c|c|c|c|c|c|}
\hline & \multicolumn{5}{|c|}{ TENSILE STRENGTH $\left(\mathrm{N} / \mathrm{mm}^{2}\right)$} \\
\hline & $\begin{array}{c}0 \% \\
\text { conventional }\end{array}$ & $\begin{array}{c}40 \% \text { replace- } \\
\text { ment }\end{array}$ & $\begin{array}{c}60 \% \\
\text { replacement }\end{array}$ & $\begin{array}{l}80 \% \text { replace- } \\
\text { ment }\end{array}$ & $\begin{array}{c}100 \% \text { replace- } \\
\text { ment }\end{array}$ \\
\hline Non-carbonated RAC & 2.43 & 2.02 & 2.07 & 2.18 & 2.203 \\
\hline Carbonated RAC & 2.43 & 2.00 & 1.96 & 2.00 & 2.00 \\
\hline
\end{tabular}




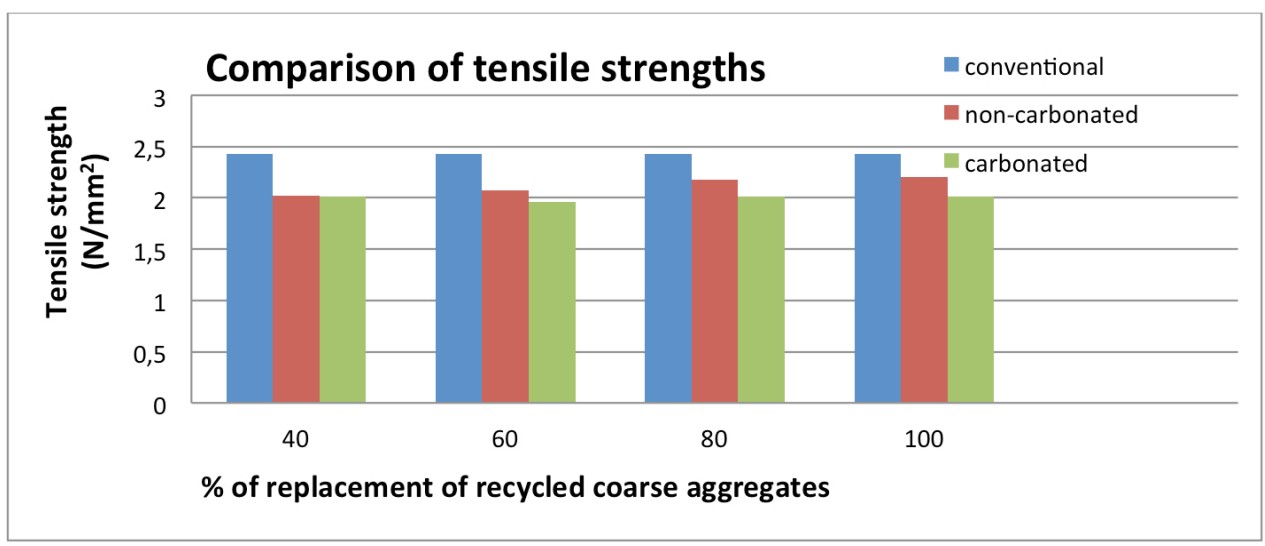

Fig. 7. Comparison of tensile strength non-carbonated and carbonated RAC with conventional concrete

\section{Conclusions}

Based on the experimental work carried out to study the properties of concrete with replacement of cement by glass powder and normal coarse RA and carbonated RA the following conclusions are drawn

1. water absorption was reduced from $2.38 \%$ to $2.17 \%$ and specific gravity of RA was increased from 3 to 3.17

2. Slump of RAC is lower than that of conventional concrete due to erosion of angularity on processing trough abrasion machine ${ }^{[\mathrm{fig} .1 \& 2]}$, slump value of carbonated RA is lower than that of carbonated RA due to reduction in water absorption on carbonation

3. It has been observed from the tests conducted on cubes that the compressive strength of concrete with glass powder as partial replacement for OPC and RA is more than conventional concrete by $9 \%$ and $2 \%$, for $40 \%$ and $60 \%$ respectively, it reduces with further increase in replacement due to reducing of bond strength as a result of abrasion.

4. The tensile strength of recycled coarse aggregate concrete shows that there is little reduction in the tensile strengths about $10-15 \%$, however the tensile strength increases as the percentage replacement increases but overall being less than conventional concrete

5. Results conclude that replacement of carbonated RA up to $80 \%$ is feasible as results lie in standards. 


\section{Acknowledgement}

We are grateful to Dr. S.S.Injagneri and Department of Civil Engineering, B.E.C. Bagalkot for the technical assistance and Lab Facilities and TEQUIP for the financial assistance for the project.

\section{References}

[1] Taha, B., \& Nounu, G. (2009). Utilizing waste recycled glass as sand/cement replacement in concrete. Journal of materials in civil engineering, 21(12), 709-721. https://doi.org/10.1061/(ASCE)0899-1561(2009)21:12(709)

[2] Shayan, A., \& Xu, A. (2004). Value-added utilisation of waste glass in concrete. Cement and concrete research, 34(1), 81-89. https://doi.org/10.1016/S0008-8846(03)00251-5

[3] Silva, R. V., De Brito, J., \& Dhir, R. K. (2014). Properties and composition of recycled aggregates from construction and demolition waste suitable for concrete production. Construction and Building Materials, 65, 201-217. https://doi.org/10.1016/j.con buildmat.2014.04.117

[4] Saravana Kumar P. and Dhinakran V, "Effect of admixed recycled aggregate on properties of concrete" Journal of Materials in Civil Engineering, Vol. 24, No. 4, April 1, 2012. (C)ASCE,

[5] Soroushian, P. (2012). Strength and durability of recycled aggregate concrete containing milled glass as partial replacement for cement. Construction and Building Materials, 29, 368-377. https://doi.org/10.1016/j.conbuildmat.2011.10.061

[6] Yixin Shao, Thibaut Lefort, Shylesh Moaras "Concrete containing glass powder" Concrete Composites, Vol. 25,2006,pp 565-575.

[7] Jiake Zhang, Caijun Shi "Performance Enhancement of Recycled Concrete Aggregates through Carbonation”10.1061/(ASCE) MT.1943-5533.0001296. (C) 2015 American Society of Civil Engineers.

\section{$7 \quad$ Authors}

Abhishek Patil is with B.E. Civil, B.E.C, Bagalkot, Department of civil engineering (abhishekpatil2991994@gmail.com, +918951218483).

Rahul Hatti is with B.E. Civil, B.E.C, Bagalkot, Department of Civil Engineering.

Darshan Patil is with B.E. Civil, B.E.C, Bagalkot, Department of Civil Engineering.

Rakesh Kumar is with B.E. Civil, B.E.C, Bagalkot, Department of Civil Engineering (NICMAR, PUNE).

Article submitted 27 September 2017 Published as resubmitted by the authors 03 November 2017. 